\title{
Transformation of potato via Agrobacterium coated microparticle bombardment
}

\author{
T.T. NGUYEN ${ }^{1,2}$, P.J. DIX ${ }^{1}$ and G.D. NUGENT ${ }^{1,3 *}$ \\ Institute of Bioengineering and Agroecology, National University of Ireland, Maynooth, Ireland ${ }^{1}$ \\ Institute for Tropical Biology, Vietnam Academy of Science and Technology, Ho Chi Minh City, Vietnam ${ }^{2}$ \\ School of Applied Sciences, Biotechnology and Environmental Biology, RMIT University, Victoria, 3083, Australia ${ }^{3}$
}

\begin{abstract}
The transformation of potato (Solanum tuberosum L. cv. Désirée) was extended by the Agrobacterium-mediated biolistic method. Using this approach transgenic shoots could be obtained at a similar frequency to that achieved through conventional biolistics. Leaves from shoot cultures were bombarded with gold particles coated in Agrobacterium tumefaciens cells harboring a binary plasmid encoding three genes of interest in the T-DNA. Nine shoots were obtained from 20 shots, with selection of transgenic shoots on a series of media containing progressively increasing concentrations of hygromycin from 5 to $20 \mathrm{mg} \mathrm{dm}^{-3}$.
\end{abstract}

Additional key words: Agrobacterium transformation, ipt gene, Solanum tuberosum, transgenic potato.

Most transformation procedures developed for potato used Agrobacterium tumefaciens (Millam 2004, 2006, Börnke et al. 2007) and a variety of traits such as starch modification, insect and virus resistance, abiotic stress tolerance and production of pharmaceutical proteins have been the goals of potato biotechnology (Börnke et al. 2007, Byun et al. 2007). Biolistic gene transfer, a method by which foreign genes may be introduced into cells via high velocity microprojectiles (Klein et al. 1988) has been used in transforming monocots such as orchids (Suwanaketchanatit et al. 2007) and dicots such as soybean (El-Shemy et al. 2007), but has only recently been used in potato. Up to 0.5 transformants per leaf shot were achieved using particle bombardment (Craig et al. 2005), almost two orders of magnitude higher than the first report in potato (Romano et al. 2003).

In order to further develop transformation systems for potato, an Agrobacterium-biolistic-mediated DNA delivery method was applied to the commercial cultivar Désirée. Agrobacterium-biolistics is a refinement to microbombardment-mediated transformation developed to counter the frequency with which broken fragments of the transgene and superfluous plasmid DNA are integrated into plant genome (Taylor and Fauquet 2002).
This strategy involves bombardment of leaf tissue with gold particles coated with Agrobacterium cells. The approach is attractive as large-scale plasmid preparations are not required and preparation and execution of experiments are much simpler. It may also reduce the incidence of multiple copy inserts often associated with biolistic delivery of plasmid DNA (Taylor and Fauquet 2002). However, there is only one report of the production of stable transformed strawberry plants using this method (De Mesa et al. 2000). We report here the application of the Agrobacterium-biolistic method to potato.

Two step shoot regeneration media and culture conditions for potato shoot cultures were as described previously (Nguyen et al. 2005). The only additional medium used here is a root induction medium (RIM) which is similar to the basal medium except $3 \%(\mathrm{~m} / \mathrm{v})$ Phytagel was used instead of agar and $0.1 \mathrm{mg} \mathrm{dm}^{-3}$ IAA was included. The binary vector pVDH396 (15890 bp) (Fig. 1), supplied in Agrobacterium tumefaciens LBA4404 strain by Dr. K. Van Dun (Rijk Zwaan Breeding, The Netherlands), contains the uidA gene (reporter gene encoding $\beta$-glucuronidase) and hpt gene (selectable marker gene encoding hygromycin phosphotransferase)

Received 15 April 2008, accepted 10 September 2008.

Abbreviations: CIM - callus induction medium; GUS - $\beta$-glucuronidase; LB - Luria and Bertani broth; PCR - polymerase chain reaction, RIM - root induction medium; SIM - shoot induction medium.

* Corresponding author; fax: (+61) 3 99257100, e-mail: gregory.nugent@rmit.edu.au 
under the control of cauliflower mosaic virus $35 \mathrm{~S}$ promoters and terminators, and the ipt gene (encoding isopentenyltransferase, responsible for the synthesis of the cytokinin, isopentenyladenine) from Agrobacterium tumefaciens, driven by the pSAG12 promoter from senescence associated gene 12 of Arabidopsis thaliana, and its terminator.

Leaves from axenic potato shoot cultures (Nguyen et al. 2005) were used as the target tissue for bombardment experiments. Two larger leaves or 5 leaflets were placed on a plastic 9-cm Petri dish abaxial side up on callus induction medium (CIM; Nguyen et al. 2005) either on the day of the bombardment experiments, or one day beforehand. Agrobacterium tumefaciens microprojectile preparation was based on the method described by De Mesa et al. (2000) with some modifications. An overnight culture of A. tumefaciens strain LBA4404 containing the plasmid pVDH396 growing in LB medium at $\mathrm{pH} 5.8$, supplemented with $50 \mathrm{mg} \mathrm{dm}^{-3}$ kanamycin and $50 \mu \mathrm{M}$ acetosyringone, was centrifuged at $70 \mathrm{~g}$. Cell pellets were then resuspended in sterile water to an absorbance, $\mathrm{A}_{600}=10$. Aliquots of $0.1 \mathrm{~cm}^{3}$ of this culture were transferred to microcentrifuge tubes and centrifuged at $6800 \mathrm{~g}$ for $1 \mathrm{~min}$. The pelleted cells were washed with $1 \mathrm{~cm}^{3}$ of tris-EDTA (TE) buffer. Cells were centrifuged and resuspended in $0.05 \mathrm{~cm}^{3}$ of TE by vortexing. An aliquot of $0.025 \mathrm{~cm}^{3}$ of gold particle solution at a concentration of $60 \mathrm{mg} \mathrm{cm}^{-3}$ was centrifuged at $16000 \mathrm{~g}$ for $1 \mathrm{~min}$, resuspended in $0.04 \mathrm{~cm}^{3}$ of the bacterial suspension and vortexed for $20 \mathrm{~s}$. A $0.005 \mathrm{~cm}^{3}$ aliquot of bacterial/Au particle mixture was spread over the centre of the each macrocarrier. After bombardment the leaf samples were incubated in dim light at $22{ }^{\circ} \mathrm{C}$ for $48 \mathrm{~h}$.

Two days after bombardment, the leaf samples were washed in sterile water and blotted dry on sterile filter paper. Bombarded leaves were cut into small pieces $(4 \times 4 \mathrm{~mm})$ and placed upside down onto CIM containing $5 \mathrm{mg} \mathrm{dm}^{-3}$ of hygromycin and $250 \mathrm{mg} \mathrm{dm}^{-3}$ cefotaxime. After 1 week, the explants were transferred onto shoot regeneration medium (SIM; Nguyen et al. 2005) containing $10 \mathrm{mg} \mathrm{dm}^{-3}$ of hygromycin and $250 \mathrm{mg} \mathrm{dm}^{-3}$ of cefotaxime. After a further 4 weeks, hygromycin resistant shoots were transferred to rooting medium

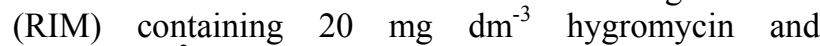
$250 \mathrm{mg} \mathrm{dm}^{-3}$ cefotaxime.

Transgene presence and integration in transgenic shoots was analysed by PCR and Southern blotting. For PCR analysis, total plant DNA from wild type and hygromycin resistant calli or shoots was isolated using the DNeasy ${ }^{\circledR}$ Plant Mini Kit (Qiagen, Valencia, CA, USA), following the kit instructions. The presence of uidA and $h p t$ was confirmed by PCR with primer pairs described previously (Craig et al. 2005) generating 365 and 508 bp products respectively. Ipt was screened for with the following primer pair: ipt forward 5'-TCAACCGGAAGCGGACGACC-3', reverse 5'-GCC ATGTTGTTTGCTAGCCA-3' product size $355 \mathrm{bp}$. The thermal cycling programs for uidA and $h p t$ were as described (Craig et al. 2005). The thermal cycling program for ipt primers was set at $94{ }^{\circ} \mathrm{C}$ for $5 \mathrm{~min}$, followed by 35 cycles at $1 \mathrm{~min}$ at $94{ }^{\circ} \mathrm{C}, 30 \mathrm{~s}$ at $60^{\circ} \mathrm{C}$ and $1 \mathrm{~min}$ at $72^{\circ} \mathrm{C}$ with a final extension at $72{ }^{\circ} \mathrm{C}$ for $7 \mathrm{~min}$.

For Southern blots, genomic DNA was extracted from leaves according to Frey (1999) with some modifications. Leaf tissue was ground in lysis buffer $(20 \mathrm{mM}$ Tris, $\mathrm{pH} 8.0 ; 20 \mathrm{mM}$ of EDTA; $2 \mathrm{M} \mathrm{NaCl}$ ), incubated at $85^{\circ} \mathrm{C}$ for $5 \mathrm{~min}$ and then placed on ice for $5 \mathrm{~min}$. This step was repeated 3 times. The microcentrifuge tubes were vortexed, and then centrifuged at $16000 \mathrm{~g}$ for $10 \mathrm{~min}$. The supernatant was RNase A $\left(30 \mathrm{mg} \mathrm{cm}^{-3}\right)$ treated and DNA precipitated and then resuspended in sterile water to a final concentration of $1 \mathrm{mg} \mathrm{cm}$. Southern blots were performed according to the method of McCabe et al. (1997) with HindIII digested DNA. PCR DIG-labelling kit (Roche Applied Science, Indianapolis, USA) was used to generate the probes. Bands on blots were visualised after incubation with chemiluminescent CDP-star for $5 \mathrm{~min}$, sealed in a plastic bag and hybridisation signals were detected by exposing the membrane to Kodak X-ray film for $1-10 \mathrm{~min}$.

Bombardment of potato leaves with gold particles coated with the large binary plasmid pVDH396 did not yield any transformed shoots (data not shown). We then tested the integration of the three genes using Agrobacterium-biolistic mediated transformation of potato with the strain LBA4404 carrying plasmid pVDH396 (hpt-ipt-uidA). Selection and transformation carried out using the same conditions for biolistic transformants (Craig et al. 2005), yielded 9 hygromycin resistant lines from 20 shots (Table 1). All hygromycin resistant lines were tested in numerous PCRs for the presence of ipt, uidA and hpt. Representative gels of some of these PCRs are shown (Fig. $1 B, C, D)$. All lines were positive for $h p t$, but some truncated T-DNA transfer may have occurred, as two transgenic lines did not carry a uidA insert (lines D2 and D3) and one line did not carry an ipt inserted gene (line D9, not shown). Seven of these 9 hygromycin resistant shoots were GUS positive according to histochemical assays (data not shown), corresponding to the same lines which were positive by PCR for uidA (Table 1). Genomic DNA from the 8 lines which were positive with PCR for ipt was extracted and digested with HindIII. In a representative blot, as expected, a band about $1.8 \mathrm{~kb}$ (the correct size of the inserted fragment) which hybridised with the DIG-

Table 1. Summary of the molecular analysis of pVDH496 transgenic potato plants generated using Agrobacteriumbiolistics. Values are the number of positive plants over the total number tested.

\begin{tabular}{llllll}
\hline Transgenic type & $\begin{array}{l}\text { GUS } \\
\text { assay }\end{array}$ & PCR & & & $\begin{array}{l}\text { Southern } \\
\text { blot } \\
\text { ipt }\end{array}$ \\
\hline LBA4404/pVDH496 & $7 / 9$ & $7 / 9$ & $9 / 9$ & $8 / 9$ & $8 / 8$ \\
\hline
\end{tabular}




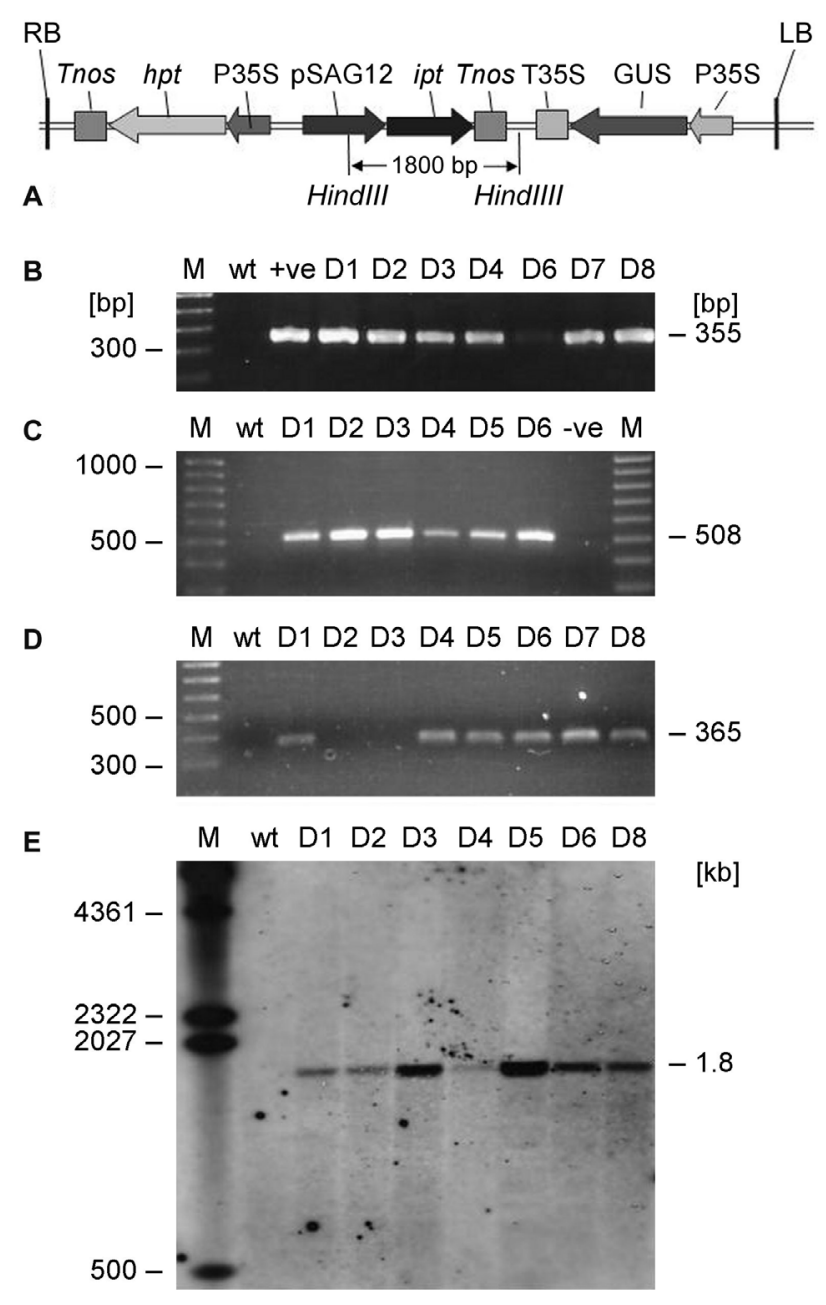

labelled ipt probe was observed only in the transgenic plants (Fig. 1E).

Whilst transgenic strawberry plants were obtained at a 2.9 times higher transformation frequency, compared with that obtained with Agrobacterium-mediated transformation, using this method (De Mesa et al. 2000), we made no direct comparison with Agrobacterium-mediated potato transformation, however the transformation frequency was similar to that previously reported using conventional biolistics with plasmid DNA (Craig et al.

\section{References}

Börnke, F., Sonnewald, U., Biemelt S.: Potato. - In: Pua, E.C., Davey, M.R. (ed.): Biotechnology in Agriculture and Forestry. Vol. 59. Transgenic Crops IV. Pp. 297-315. Springer, Berlin - Heidelberg 2007.

Byun, M.-O., Kwon, H.-B., Park, S.-C.: Recent advances in genetic engineering of potato crops for drought and saline stress tolerance. - In: Jenks, M.A., Hasegawa, P.M., Jain, M.S. (ed.): Advances in Molecular Breeding Towards Drought and Salt Tolerant Crops. Pp. 713-777. Springer, Heidelberg 2007.

Craig, W., Gargano, D., Scotti, N., Nguyen, T.T., Lao, N.T.,
Fig. 1. Generation and PCR and Southern analysis of transgenic potato plants by Agrobacterium-biolistics transformation. $A$ : Genetic map of T-DNA of binary vector pVDH396. GUSINT - uidA gene (GUS) with an intron, hpt - hygromycin phosphotransferase gene, ipt - isopentenyl transferase gene from Agrobacterium tumefaciens, LB - left border, pSAG-12 promoter from senescence associated gene 12 of Arabidopsis thaliana, $\mathrm{P} 35 \mathrm{~S}$ - CaMV $35 \mathrm{~S}$ promoter, $\mathrm{RB}$ - right border, Tnos nopaline synthase terminator, T35S - 35S terminator. $B$ : PCR using internal primers shows the presence of ipt in resistant plants via the 355 bp band. C: PCR using internal primers shows the presence of $h p t$ in resistant plants by a $508 \mathrm{bp}$ band. $D$ : PCR using internal primers shows the presence of uidA in resistant plants by a 365 bp band. E: Southern blot of transformants was probed with a $355 \mathrm{bp}$ ipt fragment. A band of approximately $1800 \mathrm{bp}$ indicates presence of T-DNA in genomic DNA. Each lane contained $10 \mu \mathrm{g}$ of genomic DNA digested with HindIII. M - contains DIG-labelled DNA molecular mass marker II (Roche). For gels $B-D: \mathrm{M}-100 \mathrm{bp}$ ladder molecular mass marker (Sigma), wt - wild type S. tuberosum cv. Désirée DNA, D1 - D8: putative transformants, +ve - positive control (pVDH396), -ve negative control, no DNA.

2005). This suggests important time and cost savings using the Agrobacterium-biolistics method, especially where 3 or more genes are to be transferred. Indeed, biolistic experiments with the purified large pVDH396 plasmid failed to deliver any transformants in our hands (data not shown), further militating in favour of the Agrobacterium-biolistics approach. However transgenic potato plants generated by bombardment containing 3 genes from one plasmid or from 3 separate plasmids has been reported (Romano et al. 2003). Using a single plasmid is preferable as $83 \%$ of transgenics expressed all three genes compared to only $6 \%$ when the three genes were co-bombarded on separate plasmids (Romano et al. 2003). Using Agrobacterium-biolistics could be a simpler option as we have shown that three genes are present in the majority of our transgenics, but we only examined expression for two of these. There is potential therefore to co-bombard with more than one Agrobacterium strain containing separate binary vectors to transfer multiple genes. However the gene integration and expression patterns would need to be determined precisely in a number of transgenics before the system could be used routinely.
Kavanagh, T.A., Dix, P.J., Cardi, T.: Direct gene transfer in potato: a comparison of particle bombardment of leaf explants and PEG-mediated transformation of protoplasts. Plant Cell Rep. 24: 603-611, 2005.

De Mesa, M.C., Bermudez, J.S., Alfaro, P., Quesada, M.A., Mercado, J.A.: Agrobacterium cells as microprojectile coating: a novel approach to enhance stable transformation rates in strawberry. - Aust. J. Plant Physiol. 27: 1093-1100, 2000.

El-Shemy, H.A., Khalafalla, M.M., Fujita, K., Ishimoto, M.: Improvement in protein quality in transgenic soybean 


\section{T.T. NGUYEN et al.}

plants. - Biol. Plant. 51: 277-284, 2007.

Frey, J.E.: Genetic flexibility of plant chloroplasts. - Nature 398: 115-116, 1999.

Klein, T.M., Fromm, M., Weissinger, A., Tomes, D., Schaaf, S., Sletten, M., Sanford, J.C.: Transfer of foreign genes into intact maize cells with high velocity microprojectiles. Proc. nat. Acad. Sci. USA 85: 4305-4309, 1988.

McCabe, M.S., Power, J.B., De Laat, A.M.M., Davey, M.R.: Detection of single-copy genes in DNA from transgenic plants by nonradioactive Southern blot analysis. - Mol. Biotechnol. 7: 79-84, 1997.

Millam, S.: Agrobacterium-mediated transformation of potato. In: Curtis, I.S. (ed.): Transgenic Crops of the WorldEssential Protocols. Pp. 257-270. Kluwer Academic Publishers, Dordrecht 2004.

Millam, S.: Potato (Solanum tuberosum L.). - In: Wang, K. (ed.): Methods in Molecular Biology. Vol. 344: Agrobacterium Protocols. Pp. 25-35. Humana Press, New Jersey 2006.

Nguyen, T.T., Nugent, G., Cardi, T., Dix, P.: Generation of homoplasmic plastid transformants of a commercial cultivar of potato (Solanum tuberosum L.). - Plant Sci. 168: 14951500, 2005.

Romano, A., Raemakers, K., Bernardi, J., Visser, R., Mooibroek, H.: Transgene organisation in potato after particle bombardment-mediated (co-)transformation using plasmids and gene cassettes. - Transgenic Res. 1192: 1-13, 2003.

Romano, A., Raemakers, K., Visser, R., Mooibroek, H.: Transformation of potato (Solanum tuberosum) using particle bombardment. - Plant Cell Rep. 12: 471-473, 2003.

Suwanaketchanatit, C., Piluek, J., Peyachoknagul, S., Huehne, P.S.: High efficiency of stable genetic transformation in Dendrobium via microprojectile bombardment. - Biol. Plant. 51: 720-777, 2007.

Taylor, N.J., Fauquet, C.M.: Microparticle bombardment as a tool in plant science and agricultural biotechnology. - DNA Cell Biol. 21: 963-977, 2002. 